\title{
A CONTRASTIVE STUDY OF THE IBIBIO AND IGBO SOUND SYSTEMS
}

\section{GOD'SPOWER ETIM}

\author{
Department Of Languages And Communication \\ Abia State Polytechnic \\ P.M.B. 7166, Aba, Abia State, Nigeria. . \\ godspoweretim0@gmail.com
}

\begin{abstract}
This research strives to contrast the consonant phonemes, vowel phonemes and tones of Ibibio and Igbo in order to describe their similarities and differences. The researcher adopted the descriptive method, and relevant data on the phonology of the two languages were gathered and analyzed within the framework of CA before making predictions and conclusions. Ibibio consists of ten vowels and fourteen consonant phonemes, while Igbo is made up of eight vowels and twenty-eight consonants. The results of contrastive analysis of the two languages showed that there are similarities as well as differences in the sound systems of the languages. There are some sounds in Ibibio which are not present in Igbo. Also many sounds are in Igbo which do not exist in Ibibio. Both languages share the phonemes /e, a, i, o, o, u, p, b, t, d, k, kp, m, n, n, j, y, f, s, j, w/. All the phonemes in Ibibio are present in Igbo except $/ \mathrm{i} /, / \mathrm{t} /$, and $/ \mathrm{N} /$. Igbo has two vowel segments $/ \mathrm{I} /$ and $/ \mathrm{\mho} /$ and also fourteen consonant phonemes /g, gb, kw, gw, $\mathrm{jw}, \mathrm{v}, \mathrm{z}, \int, \mathrm{h}, \mathrm{f}, \mathfrak{t}, \mathrm{d}, \mathrm{l}, \mathrm{r} /$ which Ibibio lacks. Both languages have high, low and downstepped tones but Ibibio further has contour or gliding tones which are not tone types in Igbo. Also, the downstepped tone in Ibibio is conventionally marked with exclamation point, while in Igbo, it is conventionally marked with a raised macron over the segments bearing it. With the assumptions of Contrastive Analysis Hypothesis (CAH), these differences may constitute learning problems to the learners of either language, while similarities may facilitate learning. The paper predicts problems and proffer solutions to helps teachers as well as learners tackle these difficulties.
\end{abstract}

Key words: Contrastive analysis; Ibibio; Igbo; Sound system; Phonemes; Tones 


\subsection{INTRODUCTION}

Nigeria is a densely populated country with many languages. The 21 st edition ethnologue data listed 509 indigenous living languages for Nigeria. Among them are Hausa, Igbo and Yoruba, which are recognized as the three languages spoken by the three major ethnic groups-Hausa, Igbo and Yoruba, while Ibibio, Tiv, Igala, Nupe, Ijaw, fulfulde, Idoma, Efik, Itsekiri, etc., are languages spoken by these minor ethnic groups. Speakers of these different languages usually come in contact in areas of endeavour such as tourism, trade/ business, education and even in hospitals and law courts. So, learning an additional indigenous language apart from one's mother tongue is necessary though these languages may be similar or different in their sound inventories and structures. It is in view of this that this research intends to look at the sound systems of Ibibio and Igbo with specific attention to segmental phonemes (consonants and vowels) and tones.

Ibibio is a tonal language spoken in the South-South region predominantly in Akwa Ibom and Cross River States. Ibibio belongs to the Lower-Cross languages, a sub-family of the (New) Benue Congo Phylum (Williamson, 1989, cited in Urua, 2000), and it is spoken by about four million people (Essien, 1990).

Igbo is one of the four official languages of Nigeria and is a member of the VoltaNiger branch of the Niger-Congo family of languages. It is spoken in Nigeria and Equatorial Guinea by about 25 million people (Wikipedia). In Nigeria, it is spoken in the South Eastern part of the country in states like Abia, Enugu, Delta, Imo, etc. According to Omniglot (an online Encyclopedia of Writing Systems and Languages), there are numerous Igbo dialects some of which are not mutually intelligible but the standard written form of Igbo is based on the Owerri and Umuahia dialects, and has been in use since 1962.

Every language has its own sound patterns. Contrastive analysis (CA) is concerned with the similarities and differences which result from the comparison between two different 
languages. In consonance with the assumption of Contrastive Analysis Hypothesis (CAH), Ibibio learners of Igbo and vice versa are prone to make errors bordering on interference, especially when they come across sounds which are not found or distributed the same way in their mother tongue respectively.

In order to help learners, this work discusses the consonants, vowels and tonal system of standard Igbo and Ibibio, predicting problems and proffering solutions which would help them in learning their target language.

\subsection{THEORETICAL APPROACH}

Contrastive analysis originated as a branch of Applied Linguistics, the aim being to solve the practical problems of language teaching and learning. Contrastive studies go back to the last decade of 19th and the beginning of the 20th century (UK Essays, 2013). It is a linguistic sub-discipline concerned with the synchronic, comparative studies of two or more languages or language varieties. Generally, both differences and similarities in the languages are studied, although the emphasis is usually placed on differences thought to lead to interference (i.e.,) negative transfer, the faulty application of structures from one's mother tongue to the second language (Trauth \& Kazzazi, 1996). Oha asserts that "Contrastive analysis has become a tool for the comparison of two language structures in terms of their similarities and differences with a view to emphasizing the points of differences in the teaching of the target language" $(2013$, p. 2). This means that contrastive analysis brings to light, the differences between the mother tongue and the target language of the learners and so makes it possible to predict the difficulties that the learners will have. This in turn determines what the learners have to learn and what the teachers have to teach. 
Lado (1957, p. 11) observes that comparing the source and the target language sound systems is "a means of predicting and describing the pronunciation problems of the speakers of a given language learning another".

Contrastive analysis according to Chesterman (1998, cited in Eme \& Uba, 2016), involves two main processes - description and comparison. This means that languages are described and compared in CA; from the comparison, potential difficulties for learners are predicted from the differences, and the extent to which the languages are alike are equally shown from the similarities.

Harris (1969, as cited in Afangideh, 2005) asserts that, through contrastive analysis, we can identify;

1) Identical language patterns in languages (identical language patterns means phonology, syntax, semantics, lexis).

2) Patterns in the target languages which have no equivalents with the L1.

3) Problems in the target language which predictably are possible points of interference, and which can become useful learning experiences.

As further explained by Afangideh:

contrastive analysis will be of immense value when target languages are being designed for learners with different linguistic backgrounds. Such an analysis would help the language teachers to determine the selective difficulty level of different patterns in the target or foreign language (p. 43).

Contrastive Analysis Model is able to predict most, if not all, of the learner's interference problems and it has proven to be a reliable and useful tool towards discovering the similarities as well as differences in the characteristic features of the languages contrasted.

As we often compare and contrast different things to see their point of sameness and divergence in terms of structure, size, components, etc., similar efforts are applied to run a 
contrastive analysis of Ibibio and Igbo, to see where they differ or resemble; and where these differences or similarities are likely to create problems or facilitate learning.

\subsection{METHODOLOGY}

This work adopts a descriptive research approach. The researcher resorted to the existing literature on the segmental phonemes and tones of both languages. On the phonology of Ibibio, this work adopts the vowel description of Essien (1990), consonant and tone description of Urua (2000). On the phonology of Igbo, this work adopts the vowel description of Iloene (2007) as used in Eme and Uba (2016); the consonant description of Eme and Odinye (2008) and the tone description of Nwachukwu (1976), Emenanjo (1978) as used in Mbah and Benjamin (2017).

\subsection{DATA PRESENTATION}

\subsection{THE SOUND SYSTEM OF IBIBIO}

The Ibibio language has twenty-four (24) segmental phonemes comprising ten (10) vowels and fourteen (14) consonants.

\subsubsection{Vocalic Phonemes of Ibibio}

There are ten (10) phonemic vowels in Ibibio. The vowels, the orthographic form, phonetic description and their distribution are seen below:

1. i /i/ a close front unrounded vowel. It occurs in ìtá, 'three' ; dí 'come'

2. $\quad \mathrm{i} / \mathrm{i} / \quad$ a centralized front unrounded vowel kím 'sew'; díp, 'hide'

3. e /e/ a half-close front vowel. ènò'gift'; mé 'endure'; dép 'buy'

4. a /a/ a central open unrounded vowel àbà 'forty'; bàt 'count'

5. $\Lambda / \Lambda /$ half-open centralized vowel with very slight lip rounding. bìk gossip; tıìk' 'grind' 
6. ə/ə/ a half-close central vowel with, lips in the neutral position. kpák 'cut into pieces'.

7. ọ/ a half- open back rounded vowel as in dòmarry j̀kôk'chewing stick'.

8. /o/ a half-close back rounded vowel. ówó 'human being'; wòt 'kill'.

9. u/u/ a close back rounded vowel. dù 'live'; únék 'dance'

10. $\mathrm{u} / \mathrm{u} / \mathrm{a}$ centralized back rounded vowel ùkù'fox', èkpú'rat'

\section{The Ibibio Vowel Chart}

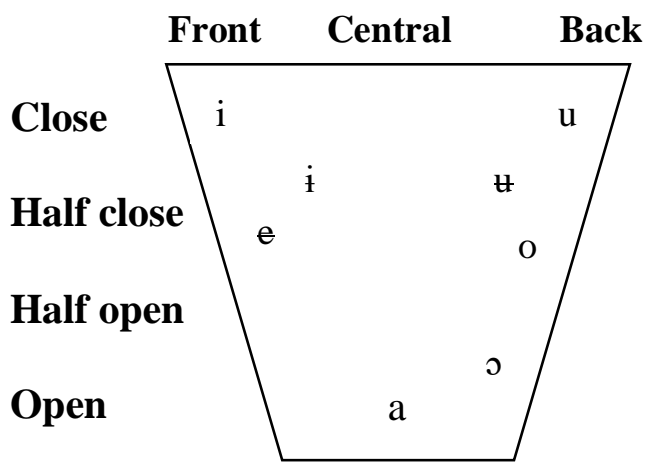

Fig. 1: Culled from Urua (2000, p. 35)

\subsubsection{Ibibio Consonant Phonemes}

There are fourteen (14) Phonemic consonants in Ibibio. Their orthographic form, phonetic description as well as distribution are shown below:

1. $\mathrm{p} / \mathrm{p} / \mathrm{a}$ voiceless bilabial stop. As in dép 'buy', típ-pé'make hole'

2. $\quad \mathrm{b} / \mathrm{b} / \quad$ voiced bilabial stop. bén 'take', èbé'husband' 
3. $\mathrm{t} / \mathrm{t}$ / voiceless alveolar stop. tóp 'throw', étôp 'massage'.

4. $\quad \mathrm{d} / \mathrm{d} / \quad$ voiced alveolar stop. dó'marry'; údón 'urge'

5. $\mathrm{k} / \mathrm{k} / \quad$ voiceless velar stop. kàá'go'; éká'mother'; dík 'enter'.

6. $\mathrm{kp} / \mathrm{kp} / \mathrm{a}$ voiceless labial velar stop. kpáy 'fold'; èkpán 'suicide'

7. $\mathrm{m} / \mathrm{m}$ a bilabial nasal. mé'endure'; ìmâm 'laughter'.

8. $\mathrm{n} / \mathrm{n} \quad$ an alveolar nasal. nò'give'; ùnén 'right/entitlement'; ǹdó'marriage'

9. ny /n/ a palatal nasal. nàm 'sell'; ńnâ 'garden egg';ǹ-jón 'personal name'.

10. $\tilde{\mathbf{n}} / \mathfrak{y} / \quad$ a velar nasal. ìnày 'river';j́-kám 'root'.

11. f /f/ a voiceless labiodentals fricative. féén 'forgive'; m̀-fìn 'today'.

12. $\mathrm{s} / \mathrm{s} / \quad$ Voiceless alveolar fricative. sín 'put'; ù-sàn 'plate'.

13. y /j/ a palatal approximant. ù-jàì 'beauty'; jém 'look for'.

14. w/w/ a labio-velar approximant. wáy 'wrap'; ú-wâ'sacrifice'.

\section{IBIBIO CONSONANT CHART}

\begin{tabular}{|l|l|l|l|l|l|l|}
\hline & Bilabial & Labiodental & Alveolar & Palatal & Labiovelar & Velar \\
\hline Stops & $\mathrm{p} \mathrm{b}$ & & $\mathrm{t} \quad \mathrm{d}$ & & $\mathrm{kp}$ & $\mathrm{k}$ \\
\hline Fricatives & & $\mathrm{f}$ & $\mathrm{s}$ & & & \\
\hline Nasals & $\mathrm{m}$ & & $\mathrm{n}$ & $\mathrm{n}$ & & $\mathrm{y}$ \\
\hline Approximant & & & & $\mathrm{j}$ & $\mathrm{w}$ & \\
\hline
\end{tabular}

Fig 2: Culled from Urua (2000, p. 38)

\subsubsection{Ibibio Tones}

Tones manifest in different ways in various languages. There are high (H), low (L) and downstepped tones in Ibibio. Other tonal realizations include a high-low (falling) and a low-high (rising) contour tones as observed by Essien (1990) and Urua (2000). The tone 
bearing units are vowels and syllabic nasals. Words may have different lexical meanings depending on its tone. For example;

1. tèm 'cook'

2. tém 'clear a bush'

3. wák 'be many'

4. wàk 'tear into pieces'

The low tone is marked by a grave accent ['], while the high tone is marked by an acute accent [']. Each of these tones can occur in all the possible environments- initial, medial and final positions. The down stepped tone is marked with an exclamation mark [!]. Unlike the low and high tones, the downstepped tone is restricted in its occurrence. The downstepped tone occurs after a preceding high tone, that is, when the pitch on the succeeding syllable of the word is slightly lower than the pitch on the preceding syllable. It does not occur at the word initial position of any word which stands in isolation.

The contour tones on the other hand occur mostly at the medial or final position of words. Below are the examples of words with the Ibibio tones:
5. sé 'look'
$\mathrm{H}$
6. nò 'give'
$\mathrm{L}$
7. kàá 'go'
L-H
8. dwว̌ 'fall'
LH
9. kèré 'be called'
L-H
10. mèèk 'bend'
L-L
11. ḿ!bók 'wrestling'
H!LH
12. ú!bók 'hand'
$\mathrm{H} ! \mathrm{H}$
13. kéré 'think'
$\mathrm{H}-\mathrm{H}$
14. ìmô 'wealth'
H-HL 


\subsection{THE SOUND SYSTEM OF IGBO}

The standard Igbo has thirty-six phonemes comprising twenty-eight consonants and eight vowels.

\subsubsection{Igbo Vowels}

There are eight phonemic vowels in standard Igbo. The vowels, their phonetic description and distribution are shown below:

1. a /a/ open front unrounded vowel. áká 'hand', àkwá 'egg', àlà 'land'

2. e /e/ half-open front unrounded vowel. éké 'python', égbé' 'kite', éféré 'plate'

3. i/i/ close front unrounded vowel. ìtè 'pot', ìsé 'five', ìrí 'ten'

4. ị/I/ half-close front unrounded vowel.ìgbà 'wooden drum', íkpà 'to weave'

5. o/o/ half-close back rounded Vowel. òròmá 'orange', ótù 'one', ólú 'neck'

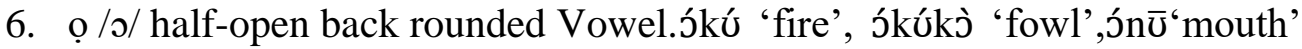

7. u/u/ close back rounded vowel. ùgwù 'honor', élú 'up', ùdó 'peace'

8. ụ/ひ/ half-close back rounded vowel.úsú 'bat', ázù 'fish', ánú 'meat'

\section{The Igbo Vowel Chart}

Front Central Back

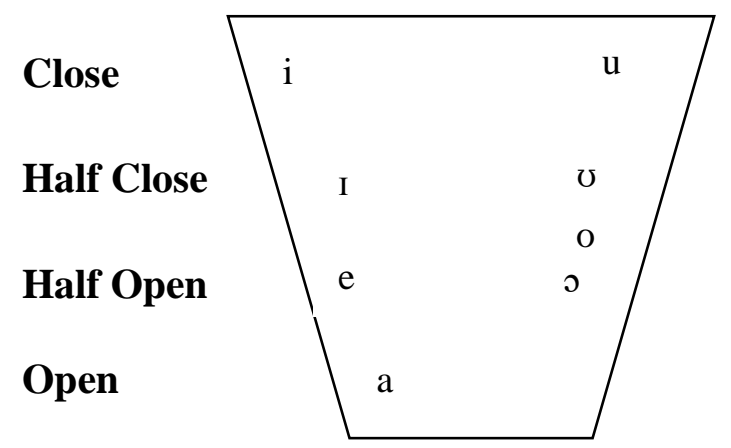

Fig. 3

\subsubsection{Igbo Consonants}


Standard Igbo has twenty-eight consonants, their orthographic representation, phonetic description and distribution are shown below:

1. $\mathrm{p} / \mathrm{p} /$ voiceless bilabial plosive. pá 'carry', àpà 'scar', pàpá 'father'

2. $\quad \mathrm{b} / \mathrm{b} /$ voiced bilabial plosive. bì 'come', bàá 'enter', mbó 'nail'

3. $\mathrm{t} / \mathrm{t} /$ voiceless alveolar plosive. tá 'chew', tòó 'praise', átúrū'sheep'

4. $\mathrm{d} / \mathrm{d} /$ voiced alveolar plosive. dèe 'write' dàá 'fall', ńdò 'life'

5. $\quad \mathrm{k} / \mathrm{k} /$ voiceless velar plosive. kèé 'share', kámà 'but', àkù ‘wealth'

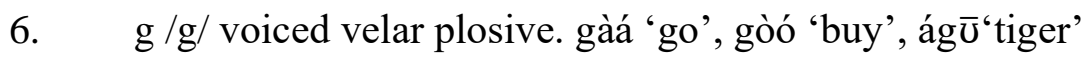

7. $\mathrm{kp} / \mathrm{kp}$ / voiceless labial-velar plosive. kpó ‘call', kpù‘mould', àkpà 'bag'

8. $\mathrm{gb} / \mathrm{gb} /$ voiced labial-velar plosive. gbàá 'kick', àgbà 'jaw', ìgbé 'box'

9. $\mathrm{kw} / \mathrm{kw} /$ voiceless labialized velar plosive. kwú 'say', kwé 'agree', ákwá 'cry'

10. gw /gw/ voiced labialized velar plosive. gwú 'dig', ígwè 'iron', àgwà 'beans'

11. $\mathrm{m} / \mathrm{m} /$ bilabial nasal. mbè 'tortoise', àmà 'witness', ímí 'nose'

12. $\mathrm{n} / \mathrm{n} /$ alveolar nasal ńnà 'father', nèé 'see', ánư ‘meat', éné 'deer'

13. ny /n/ palatal nasal. nàá 'drive', né 'give', áná 'eye',ènò. 'mirrow'

14. $\tilde{\mathrm{n}} / \mathrm{y} /$ velar nasal. yú 'drink', áná 'cane', án̄ 'bee'

15. w / yw/ labialized velar nasal. ywứdie', óywá 'moon', ènwè 'monkey'

16. $\mathrm{f} / \mathrm{f} /$ voiceless labio-dental fricative. fópù 'uproot', fùo 'get lost', áfó 'stomach'.

17. $\mathrm{v} / \mathrm{v} /$ voiced labio-dental fricative. Àví, ìvó 'names of towns/people'

18. $\mathrm{s} / \mathrm{s} /$ voiceless alveolar fricative. sòó 'pound', sèé 'draw', ósè 'pepper', àsó 'lie'

19. $\mathrm{z} / \mathrm{z} /$ voiced alveolar fricative zèé 'dodge', ż̀ó 'plant', àzú ‘back', ázù 'fish'

20. sh / $/$ / voiceless post-alveolar. Já 'crayfish', áfà 'weaver bird'

21. gh / g/ voiced velar fricative. yó 'pluck', yé 'fry', áyá 'war'

22. h /h/ voiced glottal fricative. hướ 'see', há 'they', àhư 'body', áhà 'name'

23. ch /ty/ voiceless post-alveolar affricate. tyèé 'think', ńtgà 'soap', íteè 'different' 
24. j/ḑ/ voiced post-alveolar affricate. ḑàá 'praise', ḑùó 'ask', àdzà 'sacrifice'

25. 1/1/ voiced alveolar lateral. lèé 'look', lòo 'swallow', ílú 'proverb'

26. $\mathrm{r} / \mathrm{r}$ / voiced alveolar trill rèé 'sell', èrí 'thread', érত̄'mushroom'

27. y /j/ voiced palatal approximant. jóó ‘beg’, já 'him/her/it', mjò‘sieve’

28. W/w/ voiced labialized approximant. wèré 'take', ìwú 'law', íwé ‘anger'

\section{Igbo Consonant Chart}

\begin{tabular}{|c|c|c|c|c|c|c|c|c|c|}
\hline & Bilabial & Labiodentals & Alveolar & $\begin{array}{c}\text { Post } \\
\text { Alveolar }\end{array}$ & Palatal & Velar & $\begin{array}{c}\text { Labial } \\
\text { Velar }\end{array}$ & $\begin{array}{l}\text { Labialized } \\
\text { Velar }\end{array}$ & Glottal \\
\hline Plosives & $\mathrm{b}$ & & d & & & $\mathrm{k}$ & $\mathrm{kp} \quad \mathrm{gb}$ & $\mathrm{kW}$ & \\
\hline Nasals & $\mathrm{m}$ & & $\mathrm{n}$ & & $\mathrm{n}$ & $\eta$ & & Đw & \\
\hline Fricatives & & $\mathrm{f}$ & $\mathrm{Z}$ & $\int$ & & $\gamma$ & & & $\mathrm{h}$ \\
\hline Affricates & & & & $\mathrm{t} \int \quad \mathrm{d}_{3}$ & & & & & \\
\hline Lateral & & & 1 & & & & & & \\
\hline Trill & & & $\mathrm{r}$ & & & & & & \\
\hline Approximant & & & & & $\mathrm{j}$ & & & $\mathrm{w}$ & \\
\hline
\end{tabular}

Fig.4: Eme \& Odinye, (2008, p. 28)

\subsubsection{Igbo Tonal System}

The Igbo language is a register tone language with three level tones- the high tone, low tone and downstepped tone (a reduced high tone). They are marked using acute accent ['], grave accent ['] and a raised macron over the letters ['] respectively (Emenanjo, 2015). Like in Ibibio, a word may have different lexical meanings depending on its tone.

The high and low tones can occur at all positions- initial, medial and final the downstepped tone cannot start a word in isolation and cannot follow a low tone. The downstepped tone can only occur in the middle of a word and at word final positions.

Examples of Igbo words bearing these tones are shown below:

15. ákwá 'cry', H-H 


$\begin{array}{lll}\text { 16. àkwà 'cloth' } & \mathrm{H}-\mathrm{L} \\ \text { 17. àlà 'land', } & \mathrm{L}-\mathrm{L} \\ \text { 18. òké 'rat' } & \mathrm{L}-\mathrm{H} \\ \text { 19. } & \text { àzízà 'story' } & \mathrm{L}-\mathrm{H}-\mathrm{L} \\ \text { 20. égō 'money' } & \mathrm{H}-\mathrm{S} \\ \text { 21. náāní 'only' } & \mathrm{H}-\mathrm{S}-\mathrm{H} \\ \text { 22. } & \text { ḿmírī 'water' } & \mathrm{H}-\mathrm{H}-\mathrm{S} \\ \text { 23. ákwúkwó 'book' } & \mathrm{H}-\mathrm{H}-\mathrm{H} \\ \text { 24. } & \text { ísí 'head' } & \mathrm{H}-\mathrm{H}\end{array}$

\subsection{SIMILARITIES BETWEEN IBIBIO AND IGBO SOUND SYSTEMS}

i. The six vowel phonemes-/e, a, i, o, o, u/ are basically common in the two languages

ii. The two languages share these fourteen consonant phonemes: /p, b, t, d, k, kp, m, n, n,

$$
\mathrm{y}, \mathrm{f}, \mathrm{s}, \mathrm{j}, \mathrm{w} /
$$

iii. The two languages share these voiced phonemes: /b, d, j, w, m, n, n, $\mathrm{y} /$ and also these voiceless phonemes /p, t, k, f, s, kp/

iv. Both languages have high, low and downstepped tones.

\subsection{DIFFERENCES BETWEEN IBIBIO AND IGBO SOUND SYSTEMS}

i. Ibibio has ten vowel phonemes while Igbo has eight. Four Ibibio vowels are not present in Igbo. These vowels are /u, $, \dot{\mathrm{i}}, \wedge$, ə/. Also, two Igbo vowels- $/ \mathrm{I} / \mathrm{and} / \mathrm{\mho} /$ are not present in Ibibio.

ii. Ibibio has fourteen phonemic consonants while Igbo has twenty-eight. All the Ibibio phonemic consonants are present in Igbo. There are 14 Igbo consonants - /g, gb, kw,

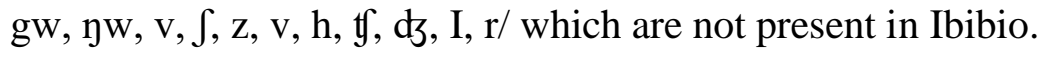


iii. The Igbo voiced sounds - /g, gb, gw, yw, v, z, v, ds, l, r, h/ and the voiceless phonemes - /kw, $\int, \mathfrak{g} /$ are not available in Ibibio.

iv. The downstepped tone in Ibibio is conventionally marked with an exclamation point, while in Igbo, it is conventionally marked with a raised macron over the segments bearing it.

v. two contour tones - high-low tone and low-high tone present in Ibibio are not in Igbo.

\subsection{IMPLICATIONS OF THE SIMILARITIES AND DIFFERENCES BETWEEN IGBO AND IBIBIO SOUND SYSTEMS}

The fundamental aim of contrastive analysis is pedagogy; that is to say that CA is a theory of language teaching/learning. When two languages are compared and contrasted, the questions that readily come to mind are which aspects of the languages are similar and which aspects are different. It is the knowledge of the similarities and differences between the two languages that will enable the language teachers to carry out their jobs effectively as well as the students to overcome their learning problems.

In this study, it is discovered that Ibibio and Igbo segmental phonemes and tones have a good number of similarities. However, several differences occur between both languages, and these differences tend to constitute pronunciation problems for the Ibibio learners of Igbo and Igbo learners of Ibibio as they would negatively transfer the habit they formed for their mother tongue (MT) or first language (L1) into their target language (TL) or second language (L2), by often substituting the unfamiliar phonemes with some familiar phonemes that do not correspond with their target language sounds.

In other words, the implication of the earlier stated differences, between the two languages' phonological patterns is that the differences lead to pedagogic problems. The reason is that when an Ibibio learner of Igbo comes across these phonemes which are absent 
in his first language, they become a problem and this also happens to an Igbo learner of Ibibio. In such cases, the learners will transfer the features in their first language to the target language.

It is discovered that there as striking similarities between the vocalic phonemes of the two languages. /e, a, i, o, o, u/ exist in both languages but /e/ and /a/ are just given different phonetic descriptions which may differ from author to author. For instance, /e/ which is a half-close front vowel and /a/ a centralised open vowel in Ibibio are half-open front vowel and open front vowel respectively in Igbo. However, this will facilitate learning as their difference is in their description and not pronunciation. The two vocalic segments /I, $v /$ in Igbo which are not in Ibibio may likely pose a problem to the Ibibio learners of Igbo as they may substitute them with somewhat similar vowels - $/ \mathbf{i} /$ and $/ \mathfrak{t} /$ in their language and vice versa for the Igbo learners of Ibibio, as the Ibibio vowels- / $\mathbf{i} /$ and $/ \mathrm{u} /$ are not present in the Igbo language. The /ə/ sound in Ibibio which is absent in Igbo may not necessarily pose a problem to the Igbo speakers, who may likely want to replace it with /e/. This is because even in the Ibibio language, /ə/ is often used in free variation with /e/ in most words. Examples: ébâk ébêk 'chin', ádéré édéré 'Sunday', ḿkpènék ḿkpènák 'a kind of timber tree'. Also, the Igbo speakers should take note of $/ \Lambda /$ in Ibibio which does not exist in their language as they may find it difficult to pronounce it.

With regards to consonants, the Ibibio phonemic consonants system is less complex compared to that of Igbo which is more complex. This will make it possible for the Igbo learners of Ibibio to learn and understand the Ibibio phonemic consonant system very fast and vice versa to the Ibibio learners of Igbo.

All the Ibibio phonemic consonants are present in Igbo. This may make learning easier for the Igbo speakers learning Ibibio. The Ibibio learners of Igbo will face a problem as most of the Igbo consonants which do not exist in Ibibio are the voiced counterparts of the voiceless sounds in Ibibio, such segments in Igbo are: /g, gb, v, z/. This will pose a serious pronunciation problem to the Ibibio learners of Igbo while pronouncing words with these segments, as they would replace them with the voiceless segments-/k, $\mathrm{kp}, \mathrm{f}, \mathrm{s} /$ in their mother tongue. The teachers should therefore, devote time to teaching their students such sounds, 
explaining the phonetics of those sounds, especially the articulatory processes involved in their production. By so doing, the difference in voicing will be properly distinguished.

The phonemic segment / $\mathrm{yw} /$ in Igbo is not phonemically present in Ibibio but phonetically realized. This may not inhibit learning, as the Ibibio speakers are aware of this sound. Other consonantal phonemes in Igbo that do not exist in Ibibio will equally be a problem to the Ibibio learners of Igbo as they would find it difficult to effectively pronounce words containing these phonemes. To avoid these problems/errors, the Ibibio learners of Igbo should study and know those Igbo sounds they are not familiar with the same should be done by the Igbo learners of Ibibio.

Concerning tones, both languages have three level tones - high, low and downstepped tones. This corroborates Mbah and Benjamin's (2017) submission that both languages belong to the terrace level type of languages. The difference is that the downstepped tone in Ibibio is marked with exclamation point, while in Igbo, it is marked with a raised macron over the segments bearing it. Also, there are contour tones - falling and rising tones in Ibibio which according to Mbah and Benjamin (2017), exist in Igbo but are not treated as tone types rather as results of tonal processes. The Ibibio learners of Igbo and vice versa should carefully note this in their studies.

Finally, from the explication of the Pedagogical problems of similarities and differences between Ibibio and Igbo segmental phonemes and tones, it is realized that learners of either language will mainly have problems in the areas of differences and this will help the language teachers as well as students emphasize the difficult areas in order to solve their linguistic problems.

\subsection{CONCLUSION/RECOMMENDATIONS}

Every language of the world has its own phonemic representations of sounds, that is, the underlying representation of various sounds that make up the language system. This study 
carried out a contrastive analysis of the segmental phonemes and tones of Ibibio and Igbo. It has so far shown that Contrastive Analysis Hypothesis is a useful tool for predicting learners' problem in the course of learning a target language.

The significant similarities and differences in the phonological features of both languages will assist greatly in solving the problems for the learners of either of the languages. With the CA results for both languages, the language teacher will be able to teach and emphasize the correct form of pronunciation of the features of either language lacking in the others. Learners of both languages would immensely benefit from this study as they will make use of the findings and discussions in this research to solve some of the pronunciation difficulties that will manifest in learning either language as the target language.

This work looked at languages as a form of communication and it emphasized the need to learn other Nigerian languages since Nigeria is a multilingual nation.

Language learning is different from language acquisition. In language learning, the knowledge of the first language influences the learning of the target language. The learners should, therefore, be motivated by the teachers, and also let to believe that, if the target language is properly learned, the learner can gain job opportunity, communicate and transact business with either of the two ethnic groups in Nigeria.

Contrastive analysis studies of the phonotactics, phonetic segments, syllable structures, morphology and syntax of the two languages should also be carried out by other researchers, as the results will greatly facilitate the learning of both languages by predicting problems and proffering solutions. 


\section{REFERENCES}

Afangeideh, M. (2005). Interference of Annang with English verb tense among different categories of secondary school students. (Unpublished Doctorial thesis), University of Nigeria, Nsukka. Retrieved August7, 2018, fromhttp://www.Unn.edu.ng/ publications/files/Interference\%20of\%20Anaan\%20with\%20English\%20Verb\%20Te nse\%20Among\%20Different\%20Categories\%of\%20Secondary\%20School\%20Studen t_l.pdf

Bussmann, H. (1996). Routledge Dictionary of Language and Linguistics. (Trauth, G. \& Kazzazi, K., Trans. \& Eds.). London: Routledge.

Eme, C \& Odinye, S. (2008). Phonology of standard Chinese and Igbo: Implications for students learning Chinese. Nkuzi na Oтити Asusu (Nkoa) Journal, 1, 26-37. Retrieved August 4, 2018, from https://wwwresearchgate.net/publication/305639391Phonology-of-Standad-Chinese-and-Igbo-implication-for-Igbo-student-learningchinese.

Eme, C. \& Uba, E. (2016). A Contrastive Study of the Phonology of Igbo and Yoruba. Unizik Journal of Arts and Humanities (UJAH), 17(1), 6583.http://dx.doi.org//10.4314/ujah.V17i1.4

Emenanjo, N. (2015). A grammar of contemporary Igbo: Constituents, features and processes. Port-Harcourt: M and J. Grand orbit Communications.

Essien, O. (1990). A Grammar of the Ibibio Language. Ibadan: University Press.

\section{http://en.Wikipedia.org./Wiki/Igbo-languageIgbolanguage}

Igbo Language, Alphabet and Pronunciation. Omniglot: The Online Encyclopedia of Writing Systems and Languages (n.d). Omniglot.com

Lado, R. (1957). Linguistics across cultures, applied linguistics for language teachers. Ann Arbor: The University of Michigan Press.

Mbah, B. \& Benjamin, R. (2017). A comparative analysis of the tone systems of Ibibio and Igbo. Igbo Language Studies, 2, 13-132. Retrieved August 4, 2018, from http://www.ils.okwuigbo.org/media/files/010-Mbah-113-132.pdf

Oha, A. (2013). Analysing Igbo Second Language Phonology. Journal of Linguistics Association of Nigeria (JOLAN), 16 (1 \& 2), 1-24.

Simons, Gary, F \& Charles, D. (Eds.). (2018). Nigeria Ethologue (21st.ed.). Retrieved August 1, 2018, from https//www.ethologue.com/country/NG

UK Essays. (2013). Contrastive analysis hypothesis. Arnold: UK Essays. Retrieved August 30, from https://www.ukessays.com/essays/english-language/towards-theclassification-ofcontrastive-studies-english-language-essay.php?vref=1

Urua, E. (2000). Ibibio phonetics and phonology (2nd.) Port Harcourt: M \&J Grand Orbit Communications. 